\title{
Firm Size and Tax Saving Behaviour of Listed Companies in Nigeria
}

\author{
Joseph U. Madugba' \\ E. Ben-Caleb ${ }^{1}$ \\ Adedoyin I. Lawal ${ }^{1^{*}}$ \\ Uche T. Agburuga ${ }^{2}$ \\ ${ }^{1}$ Department Accounting and Finance, \\ Landmark University, \\ Omu-Aran, Kwara State, Nigeria \\ ${ }^{2}$ Accounting and Bursary Departments, \\ Federal University Otuoke, \\ Bayelsa State, Nigeria \\ ${ }^{*}$ Corresponding Author
}

Doi: 10.36941/ajis-2020-0054

\section{Abstract}

In this paper has been investigated tax savings behaviour of firms in Nigeria with the objective of finding out how it affects firm size. The ex-post facto research design was employed, and secondary data obtained from the annual reports of firms listed on the Nigeria Stock Exchange was used. Descriptive statistics and panel data regression tests were conducted. The data were further subjected to unit root test to establish the stationarity of the data. The result revealed that interest tax savings behaviour and depreciation savings behaviour have negative but significant relationship with firm size while effective tax rate has negative and insignificant relationship with firm size. The study concluded that the lower the firm size the higher the tax savings behaviour and vice versa of quoted companies in Nigeria. The paper recommended that tax regulatory authorities should focus their searchlight on tax aggressiveness of small sized companies as a strategy to reduce tax evasion while encouraging appropriate tax savings strategies to ensure tax compliance.

Keywords: Interest tax savings, depreciation tax savings, effective tax rate

\section{Introduction}

Tax payments naturally reduce the amount of profit or income available for distribution. Hence, the desire by taxpayers to ensure that the extent to which their profit or income is reduced by taxes will be very minimal.Tax savings behaviours is used here to mean the methods employed by taxpayers to calculate tax payments in such a way to legally curtail the amount of tax paid. The Government on the other hand is anxious to generate revenue for smooth administration of government hence stiff penalties are imposed on taxpayers for non-compliance with tax laws. Such penalties may include imposition of levies and penalty payments, forfeiture of property or in extreme cases of violation of tax laws penalties may mean imprisonment as may be decided by a court of competent jurisdiction 
(Isola et al, 2015; Lawal et al 2018a; 2019a). However, there is no tax legislation that compels its citizens to pay more than required therefore it is rational that taxpayers may wish to explore relevant provisions in the tax laws to reduce the amount of tax that they pay to the relevant tax authorities. Consequently, tax payer behavior often tend towards engaging in tax avoidance to ensure that less possible tax is paid without infringement and thereby make tax savings. Ariwodola (1991), "posit that tax saving is concerned with maximizing opportunities created in tax legislations to trim down or reschedule tax payment within the scope of tax law". Hanlon and Heitzman (2010) stated that tax savings is any diminution in explicit taxes. It embraces all legal means employed by individual or corporate taxpayers with the objective of maximizing allowances, exemptions and reliefs are fully browbeaten.

It is trite to aver that one of these strategies usually adopted is the timing of acquisitions and disposals of fixed assets. This is to ensure that the date when a profit is earned and when such profit is subjected to tax leads to maximum tax advantage of the taxpayer. In addition, the date at which a business ceases operation will also impact on its tax liability. A cognisant taxpayer with a professional skill of tax policy can exploit such prospect to diminish the tax charge that otherwise would be billed. Therefore, the management of business organizations needs scrupulous facts of tax laws and their appliance to fastidious condition in recognizing and winning advantages of the rules to maximise tax savings .However, the issue of tax saving and the best suitable scheme to be employed that would not violate the law has been the dilemma of tax payers since time immemorial and such behaviours are common in everywhere taxes are imposed. Much concerned are corporations considering how taxes obviously trim down their distributable earnings and this could be the ideology for the incessant seek for tax reduction. While the payment of more taxes help to increase the funds available to the government for the improvement of the society, Firms need not pay their fair share in order to minimize effect of tax on the affluence of equity holders (Frank \& Rego, 2009, Fisher \& Warpole, 2005, Egger, Eggert \& Winner, 2010, Isola et al, 2015, Fashina et al, 2018, Lawal et al, 2018, Dahunsi et al, 2019a, 2019b).

Armstrong, Blouin, Jagolinger, and Larcker (2013) opined that tax saving is a crucial investment decision that business managers ought to make to improve shareholders value. Well, it is expected that factors that influence firms' overall investment strategy and position would most likely affect its size; it is however uncertain whether tax savings determine firm sizes or whether the size of firms informs about the tax saving behaviour. Even as the direction of causality is uncertain there may be several other causative factors that could drive tax saving strategy. An understanding of these factors would be a plus to properly position corporate decision makers to take advantage of the possibilities for increasing value for the investors.

One good strategy to reduce higher income tax is using debt instruments and leverage because it shields income from taxes (Myres1984, Shun 1996 and Graham 2003, Okere et al, 2019). Graham and Alan (2006) opined that differences in marginal tax rate for corporations' influence decision about equity and debt financing. Tax considerations affect an organizations financing decision but the level of such an effect is mostly not significant (Graham, 2003). Besides shielding tax with debt or leverage structure, it has also been established that tax strategy could also involve using non-monetary saving such as depreciation to reduce the amount of taxes paid by corporation. This implies that investment in fixed asset is a good strategy that can be employed with much success (Onaolapo \& Kajola, 2010, Otekunrin et al, 2018).

It is apposite to assert that due consideration of the growth of firms can only be sustained through the provision of value-added services in the operating activities as this has a direct effect on revenue generation. This however can only meaningfully create shareholder value when complemented by the tax savings behaviour of the firm. Given the increasingly difficult business environment of Nigeria which is negatively affected by the fluctuation and decline in oil prices in the international market a study of tax saving behaviour of firms could reveal the strategies employed to navigate the hash economic climate. Several authors have engaged the issues of tax competition etc in developed countries such as United States, Australia and Japan (Zimmerman, 1983; Gupta \& 
Newberry, 1997; Buijink, Janssen \& Schols, 2002; Feeny, Harris \& Gillman, 2002; and Janssen, 2005). However, despite the passionate and belligerent tax planning activities of firms in developing countries like Nigeria where commitment to tax payment is very low, researchers are becoming more curious as to the tax savings behaviour. It is particularly imperative to study tax savings behaviour of firms in Nigeria considering the complaint over high tax rates which reduces their profitability and shareholder value creation.

In extant literature are studies of Rego (2003), Miraz \& Javed (2013) Rego \& Wilson (2012), Wang (2010) Wilson (2009) and Mills (1996) which are in developed countries of the world. The study of Kiabel and Akenbor (2014) though in Nigeria did not use the same variables and focused only on the manufacturing sector. Hence, the need for this research to assess the relationship of firm size and tax saving behaviour of quoted firms in Nigeria.

\section{Literature Review}

\subsection{Firm size and tax savings strategy}

As a corporation increases in size, operations and earnings, the taxes paid by such corporation increases flanking their earnings, therefore the urgent desire to curb the taxes and enhance profit. At this point, services of expertise will be necessary to ensure that tax can be reduced legally. Permit to say that big corporations overlook bankruptcy risks as noteworthy in determining the size of leverage as fixed costs constitute only a small part of corporate value. More so, big firms are more mindful of diversification hence give little consideration to bankruptcy risks (Titman \& Wessel, 1988). The bigger the firm the more tends to behave as if it is too big to fail. In line with this, there exists a link between size and the ability of such firm to adopt the tax saving strategy of taking more debts to reduce corporate tax. Secondly, Rajan and Zingales (1995) found that firms that are above the median size in their sample are much more willing to issue equity if their profitability is above the median. What this implies is that the use of debt to shield tax payments is a function of firm size and those bigger and more profitable firms tend to use less debt financing. Consequently, mega corporations tend to use common stock financing much more than debt, hence discount the saving that may arise from debt tax shielding. However, as firms use more of equity and less debt to expand the assets, the earn some advantage in tax saving process in the form of depreciation tax savings, thereby permitting significant association between size and tax saving of firm.

\subsection{Firm Size, corporate performance and Implications for Tax Savings Behaviour}

The size of a corporation absolutely affects its achievement because it determines the economies of scale enjoyed by the firm. Bigger corporations have wider opportunities and can exploit the high leverage ratio resourcefully with comparative positive returns. Conversely, larger size, if not well managed leads to adverse returns as a result of huge fixed cost outlays. On the other hand, small firms have greater difficulty in securing debt financing when compared to large corporations. The larger the corporation is, the greater its opportunity to attract debt instrument since lenders consider the capacity of the creditor to pay back. In this regard, large corporations is seen as having the capacity and collateral for repayment of debt hence investors are more fascinated in buying the debt instrument of large firms than that of small firms. Considering the tax shield of debt instruments, it is intuitive to assert that the size of a firm affects corporate performance positively. The size of a corporation is measured with total asset of the corporation in several extant studies (Zeitun \& Tian ,2007; Onaolapo \& Kajola, 2010).

\subsection{Depreciation and Amortization Tax Saving Strategy}

Depreciation is the allocation of the cost of long-lived asset to the period that benefit from the use of 
such asset. In business, the purchase of fixed asset for use in the business is seen as investment because it leads to out flow of fund with the potential to generate future benefits. To encourage investments outlays, such out flow is usually compensated with capital allowance deductions that are not taxable that usually approximates the depreciation charge. In the real sense depreciation is a provision for the replacement of the fixed asset at the end of the expected useful economic life end. In taxation, because there are various methods for calculation of depreciation and depreciation being a function of company's policy, section 21(g) of Personal Income Tax Act of 1993 as amended to date, treat it as non-allowable expenditure but the $5^{\text {th }}$ Schedule of the same Act in compensation for purchase and use of fixed asset in business, made provision for capital allowance in place of depreciation. Abbas, Bashir and Akram (2013) in their study found firm's performance and tax saving strategy to be significantly affected by depreciation and other non-debt tax shielding strategies that can be effectively employed by companies. Non-debt tax shield are those other items different from interest expense that contribute to the reduction in tax payment obligation. For instance, tax deduction for depreciation and bad debts are labelled as non- debt tax saving strategies. Bauer (2004) opined that corporation with enough tax credit from investment or depreciation deductions are likely to use less debt financing as a tax saving strategy as cited in Kuok and Said (2012).

Consequently, firms with huge fixed asset investment may opt to use depreciation as tax saver rather than interest expense; this behaviour may be informed by the need to stave off possible cost of bankruptcy that more debts can generate when they are overused. Dare and Sola (2010) and Shenoy \& Koch (1996) asserted that depreciation serves as a noninterest expense strategy that can be employed by corporations to save tax payment obligations.

\subsection{Expense Tax Saving Strategy}

Tax is always paid after business expenses. Operating expenses are deducted from the available profit and the remaining balance is subject to tax at the prevailing tax rate. Intuitively, it is possible for companies to inflate their operational and administrative expenses in such a way that would significantly reduce the taxable profit. Companies might increase perquisites and other non-salary benefits to their employees to boost operational cost. The practice in some foreign companies is to pay their staff salary that approximates what they pay in their home countries which is way out of the prevailing salary scale in the local environment rather than surrender such monies to the government as taxes. Paying huge salaries to these staff will boost their morale and benefit the company in the long run. This practice amounts to indirect tax saving behaviour as it reduces the tax payable of such company.

\subsection{Theoretical Framework}

\subsubsection{Hoffman's Tax Planning Theory.}

The Hoffman tax planning theory posits that a taxpayer has the prerogative to direct his activities to the extent that the tax arising from such acts will be minimal. He/she is not under any obligation to engage in activities that will increase the tax payable beyond the minimum tax. If the taxpayer successfully minimizes his tax, to the smallest amount, the tax authority will not mandate him to increase business activities as to pay a higher tax. This theory is the basis of tax planning. The Hoffman theory stressed that tax planning is good provided it reduces chargeable profit, without forgoing accounting income. This is because the tax payable is a function of taxable profit and not business profit. Tax planning essentially is geared towards accelerating business operations that increase accounting profit but decrease chargeable or taxable profit. Tax Planning is concerned about how a taxpayer can legally reduce tax liability without infringing on tax laws. This study is anchored on the Hoffman tax planning theory that espouses a strong association between tax planning and firm performance by focusing on the tax saving behaviour of firms of different sizes. 


\subsection{Empirical Review}

Shabbir, Waheed and Mahmood (2017) examined tax optimization and firm value in the context of Pakistan. The concern of their study was to investigate the relationship between tax optimization and firm value in Pakistan. This study employed effective tax rates as a determinant of firm value. Debt, earnings management and audit quality was also considered in the study. Balance panel data with 381 non-financial firms and 2280 total number of observations were used. The study covered a six year period from 2009 to 2014. Panel data regression analysis was carried out with the aid of e-views software and the outcome revealed that tax optimization, accruals and audit quality increase the firm value.

The study by Salawu, Ogundipe and Yeye (2017) examined levin causality between corporate tax planning and firm value of non-financial quoted companies in Nigeria. The scope of the study was for a period of 11 years from 2004 and 2014. Secondary data from 50 non-financial companies listed on the Nigerian Stock Exchange (NSE) which cut across ten sectors were collected from the audited annual financial reports. of the sampled firms. The pair wise vector auto-regressive (VAR) granger causality test showed that there is no causality between tax planning and firm value within the sampled period at $5 \%$ level of significance.

The effect of tax planning and firm value was also the object of the study by Nwaobia, Kwarbai and Ogundajo (2016). The research design for the study was ex-post facto and the sample size of the study was fifty (50) companies between periods 2010-2014. Secondary data gotten annual reports of the companies were used. Descriptive and inferential statistics focussed on pooled panel data regression model was adopted. Firm size was considered as an independent variable which we have here identified as one of the determinants of tax saving. The result showed that tax planning proxies on the firm value was significant effect on firm value.

A similar study conducted by Ftouchi, Ayed and Zemzem (2014) also investigated tax planning and firm value focusing on evidence from European companies. Firm value is the dependent variable measured by Tobin's $Q$ while tax planning is the independent variable measured by effective tax rate, tax savings, and control variables include tangible assets, leverage, and dividend per share and plant and equipment size. The study covered the period 2008-2012 and found a significant and positive association between tax planning and firm value. Also, the correlation co-efficient between various independence and control variables were significant.

The current study builds on these previous ones by focusing on the relationship of firm size and tax savings behaviour rather than on tax planning. Firm Size was measured by log of total assets while the various tax saving mechanism such as interest tax expense savings, depreciation tax expense savings comprise the dependent variables. The effective tax rate which has been used as a measure of tax planning is serving as the control.

\section{Research Method}

The study adopted ex-post facto design. This design is adopted because data for both dependent and independent variables already exist and is not subject to bias. The population of the study is 198 actively quoted companies in Nigeria were selected and the period of study was 2010-2018. The data for the study were sourced from the annual reports and accounts of the companies in our study which cut across various sector of Nigeria economy. Base on the availability of data required for study, fifty-two (52) companies where selected. Descriptive statistics, Cointegration test and of course unit root test was also carried out to establish the stationarity of the data. The fixed and random effects both of the panel data regression was used to test the hypotheses and with help of Hauseman test, the most preferred of the regressions was made and used for interpretation. The tested variable is firm size measured by log of total asset while the predictor variables are interest tax expenses (NTAX), depreciation and amortization tax expenses (DTAX) and effective tax rate (EFTAX). The eview 9 software was used to conduct a multiple regression analysis of the panel data regression. 
Model specification

Tasst $_{i t}=\breve{\alpha}+\beta_{1}$ ntax $_{i t}+\beta_{2}$ dtax $_{i t}+\beta_{3}$ eftax $_{i t}+u_{o}$

Where

Tasst $=$ Firm size measured by log of total asset of the firms

Ntax $\quad$ Interest tax expense savings

Dtax $\quad=\quad$ Depreciation and amortization tax savings

Eftax = Effective tax rate.

Following Lawal et al, 2016, 2018, Nakaya et al, 2020, Yang, et al, 2018, Ho et al, 2016, Dahunsi et al, 2019a, Dahunsi et al, 2019b, Cho et al, 2017, we developed the multiple regression analysis as follows:

$$
Q_{\tau k}{ }^{\left.y_{i} / x_{i}\right)}=x_{i} \beta_{\tau k}
$$

Where $y_{i}=\left(y_{i 1} \ldots \ldots \ldots y_{i n i}\right)^{\mathrm{T}}, x_{i}=\left(x_{i 1} \ldots \ldots \ldots \ldots y_{i n i}\right)^{\mathrm{T}}$ is an $\left(m_{i} * \rho\right)$ dimensional matrix of the $\mathrm{i}^{\text {th }}$ subject, $\beta_{\tau k=}\left(\beta_{\tau k, 1, \cdots \cdots \ldots . . .} \beta_{\tau k, p}\right)^{\mathrm{T}}$ is a $\rho$-dimesional parameter vector of the $\tau k^{\text {th }}$ estimates. When we estimate the dimensional parameter simultaneously, we get

$$
\sum_{i=1}^{n} X_{i}^{T} A_{i}^{-\frac{1}{2}} R_{1}(\delta)^{-1} A_{i}^{-\frac{1}{2}} \varphi\left(Y_{i}-X_{i} \beta\right)=0
$$

Here, $\left(y_{i 1} \ldots \ldots \ldots y_{i n i}\right)^{\mathrm{T}}, X_{i}=I_{k} \otimes X_{i}$ defined by a left Kronecker product operator $\otimes$ and a $(\mathrm{K}$ $\left.{ }^{*} \mathrm{~K}\right)$-dimensional identity matrix $\left.I_{k}, \beta=\left(\beta_{\tau k, 1}, \ldots \ldots \ldots \beta_{\tau k, p}\right)^{\mathrm{T}},\left(Y_{i}-X_{i} \beta\right)=\varphi_{\tau k}\left(Y_{i}-X_{i} \beta\right)^{\mathrm{T}}\right)^{\mathrm{T}}$, and $A_{i}$ and $R_{i}(\delta)$ are an $\left(m_{1} K * m_{1} K\right)$ - dimensional diagonal variance matrix and a working correlation of $\varphi\left(Y_{i}-X_{i} \beta\right)$ respectively.

\section{Data analysis and Interpretation}

Table 4.1: Descriptive Statistics

\begin{tabular}{|l|c|c|c|c|}
\hline Variable & Tasset & Ntaxs & Dtaxs & Eftax \\
\hline Mean & 7.465331 & 4.243312 & 2.254069 & -13.03126 \\
\hline Median & 7.300000 & 3.310000 & 1.330000 & -18.05000 \\
\hline Maximum & 9.640000 & 37.81000 & 28.77000 & 806.6800 \\
\hline Minimum & 5.710000 & 0.070000 & 0.000000 & -755.6700 \\
\hline
\end{tabular}

Source: Researchers computation from E-9 result, 2019

Statistical evidence from table 4.1 above indicated that the tested variable firm size measured by total assets has a mean value of 7.465331. This implies that firm size positive and exercises control over the predictor variables. Interest tax savings, Depreciation tax savings and effective tax rates are shown to have mean values of 4.243312, 2.254069 and -13.03126 respectively. Except for effective tax rate that is shown to have negative value, others are positive and hence influence the tested variable to an extent. We that we proceed to unit root test to establish the stationarity of the data variables in our study.

Table 4.2: Result of Unit Root Test

\begin{tabular}{|c|l|c|c|c|}
\hline Variable & Method & At levels & At first difference & Order of integration \\
\hline \multirow{4}{*}{ Tasset } & Levin, Lin \& Chu (2002) & 2.61575 & $-21.3496^{* * *}$ & \\
\cline { 2 - 4 } & Im, Pesaran and Shin (2003) & $6.43649^{* *}$ & $-5.43145^{* * *}$ & \multirow{2}{*}{$1(1)$} \\
\cline { 2 - 4 } & ADF - Fisher Chi-square & $41.9874^{* *}$ & $167.818^{* * *}$ & \\
\cline { 2 - 4 } & PP - Fisher Chi-square & $40.7875^{* *}$ & $197.446^{* * *}$ & \\
\hline \multirow{4}{*}{ Ntaxs } & Levin, Lin \& Chu (2002) & $-8.16908^{* * *}$ & $-31.3366^{* * *}$ & \\
\cline { 2 - 4 } & Im, Pesaran and Shin (2003) & 0.14559 & $-8.98263^{* * *}$ & \multirow{2}{*}{$1(1)$} \\
\cline { 2 - 4 } & ADF - Fisher Chi-square & 110.308 & $206.459^{* * *}$ & \\
\cline { 2 - 4 } & PP - Fisher Chi-square & 116.341 & $225.721^{* * *}$ & \\
\hline
\end{tabular}




\begin{tabular}{|c|l|l|l|l|}
\hline Variable & Method & At levels & At first difference & Order of integration \\
\hline \multirow{4}{*}{ Dtaxs } & Levin, Lin \& Chu (2002) & $-116.229^{* * *}$ & & \multirow{2}{*}{1 1(o) } \\
\cline { 2 - 4 } & Im, Pesaran and Shin (2003) & $-15.4026^{* * *}$ & & \\
\cline { 2 - 4 } & ADF - Fisher Chi-square & $158.850^{* * *}$ & & \\
\cline { 2 - 4 } & PP - Fisher Chi-square & $198.927^{* * *}$ & & \multirow{2}{*}{$1(0)$} \\
\hline \multirow{4}{*}{ Eftax } & Levin, Lin \& Chu (2002) & $-25.2792^{* * *}$ & & \\
\cline { 2 - 4 } & Im, Pesaran and Shin (2003) & $-5.27070^{* * *}$ & & \\
\cline { 2 - 4 } & ADF - Fisher Chi-square & $197.998^{* * *}$ & & \\
\cline { 2 - 4 } & PP - Fisher Chi-square & $240.802^{* * *}$ & & \\
\hline
\end{tabular}

Note: ${ }^{* * *}$ significant at $5 \%$ level, ${ }^{* * *}$ significant at $10 \%$ level.

Granger and Newbold (1974) and Granger (1986) have shown that if panel variables are nonstationary, the panel econometric study becomes inadequate. That is, regression coefficients with non-stationary variables would more than likely yield spurious and misleading results. It thus indicates that the panel variables must be stationary (finite means, variance and auto variance) for them to be valid. To overcome this problem, we test for stationarity of the dependent and independent variables employing the summary Unit Root Test comprising Levin, Lin, Chu t, Im Pesaran and Sin w-stat, PP and ADF tests. The results of the tests are presented in Table 4.2., which indicates that the balanced panel data of both the dependent and independent variables in our study is stationery at levels, first or second difference. This implies that the data is stationary and therefore a balanced panel data that can be used for effective regression analysis for the test of hypotheses. Permit to say that because there is no long run association between the variables in our study, we immediately proceeded to multiple regression analysis for the test of hypotheses.

\subsection{Test of Hypotheses}

Hypotheses one

$\mathrm{Ho}_{1}$ The effect of firm size on interest tax expenses, depreciation tax savings and effective tax rate of listed firms in Nigeria is not significant.

Decision rule: Accept the null hypothesis if the probability computed by means of E- view 9 is less than or equal $0.05(\mathrm{p} \leq 0.05)$.

Table 4.3: Result of fixed and random effect regression test of the effect firm size and interest tax savings, depreciation tax savings and effective tax rate of listed companies in Nigeria.

\begin{tabular}{|c|c|c|c|c|c|c|}
\hline \multirow{2}{*}{ Variable } & \multicolumn{3}{|c|}{ Fixed effect of panel data regression } & \multicolumn{3}{|c|}{ Random effect of panel data regression } \\
\hline & Co-efficient & t-statistic & Prob & Co-efficient & t-statistic & Prob \\
\hline NTAXS & -0.052606 & -4.470878 & $0.0000^{* *}$ & -0.053610 & -4.560719 & $0.0000^{* *}$ \\
\hline DTAXS & -0.082006 & -4.749154 & $0.0000^{* *}$ & -0.075853 & -4.466503 & $0.0000^{* *}$ \\
\hline EFTAX & -0.000382 & -0.601387 & 0.5480 & -0.000405 & -0.637355 & 0.5244 \\
\hline $\mathrm{C}$ & 7.868422 & 102.0608 & 0.0000 & 7.858519 & 102.2432 & 0.0000 \\
\hline \multicolumn{2}{|c|}{ R-squared } & \multicolumn{2}{|l|}{0.153972} & ared & \multicolumn{2}{|c|}{0.140641} \\
\hline \multicolumn{2}{|c|}{ AdjustedR-Squared } & \multicolumn{2}{|l|}{0.131998} & Adjusted R-Squared & \multicolumn{2}{|c|}{0.132405} \\
\hline \multicolumn{2}{|c|}{ DurbinWatsonStat } & \multicolumn{2}{|l|}{0.164900} & DurbinWatson Stat & \multicolumn{2}{|c|}{0.166261} \\
\hline \multicolumn{2}{|c|}{ F-Statistic } & \multicolumn{2}{|l|}{7.006784} & -Statistic & \multicolumn{2}{|c|}{17.07505} \\
\hline \multicolumn{2}{|c|}{ Prob(F-statistic) } & 0.000000 & \multicolumn{2}{|c|}{ Pro (F-statistic) } & \multicolumn{2}{|c|}{0.000000} \\
\hline
\end{tabular}

Table 4.4: Result of Hausman test

Test Summary

Period random
Chi-Sq. Statistic 4.768083
Chi-Sq. d.f.

Prob.

0.1896


Statistical evidence from our test conducted using the Hausman test suggest that the random effect of the panel data regression is preferred to the fixed effect model of the panel data regression analysis as can be seen from table 4.4 above. Hence, our discussion of result will base on the random effect model of the panel data regression analysis.

\subsection{Discussion of Result}

Evidence from table 4.3 above indicates that Interest tax expenses are shown to have a co-efficient of regression value of -0.053610 . This implies that interest tax expenses are negative but a significant determinant of firm size. This result suggests that the larger the firm size the lower the interest tax expense. What this means is that while small sized firms use interest expense tax saving to reduce their tax liability since interest expenses are tax deductible, large firms do not behave that way. This finding corroborates the finding of Nwaobia and Jayeoba (2016) which was also carried out in Nigeria but negates those of Ftouchi, Ayed and Zemzem (2014), a study conducted in a developed country. Furthermore, depreciation tax expense is identified with a co-efficient of regression value of -0.075853. This result confirmed that depreciation tax expense is negative but significantly affects firms' size. The finding contributes to the literature as a previous study conducted by Nwaobia, Kwarbai and Ogundajo (2016) in Nigeria did not consider depreciation tax expense as a variable for tax saving strategy. This study also differs from the foregoing which focused on the manufacturing sector while this study considered a cross section of all the quoted companies in Nigeria.

The result of the random effect of the panel data regression test in Table 4.3 above shows that effective tax rate is negatively and insignificantly related with firm size as evidenced by co-efficient of regression value of -0.000405. This indicates that effective tax rate does not significantly influence tax saving behaviour irrespective of the size of the firm.

Well, the adjusted co-efficient of multiple determination of 0.132405 indicates that about $13.24 \%$ of the changes in firm size is determined by changes in the predictor variables (interest tax expenses, depreciation tax expenses, and effective tax rate) while other factors not captured in the model accounts for the rest of the variation. However, the model is significant in explaining the relationship between the dependent and the independent variables. The F-statistic of 17.07505 is significant at $5 \%$ level and this further highlight the appropriateness of the model specification. The probability value of 0.000000 showed that at $5 \%$ level of significance, the null hypotheses can be accepted.

\section{Conclusion and Recommendations}

The result shows that the proxies for tax savings behaviour that is both the interest expense tax saving and depreciation tax savings are determinants of firm size of listed companies in Nigeria. The control variable of effective tax rate is not significant. Therefore, we conclude that tax saving behaviour have significant effect on the firm size of listed companies in Nigeria.

From the result of the tested hypothesis as contained in the table 1 above, we conclude that tax savings strategies negative but significantly affect on firm size of listed companies in Nigeria.

\subsection{Recommendations}

From the conclusion of this study, we recommend as follows:

That there is urgent need for continuous review of operations by quoted firms to ensure effective and efficient application of tax saving strategies which will enhance the firm's performance.

That tax authorities should more vigilant to ensure that the tax savings behaviour is well within the ambits of the law in the financial statement of the quoted firms in Nigeria. Tax regulatory authorities should focus their searchlight on tax aggressiveness of small sized companies as a strategy to reduce tax evasion while encouraging appropriate tax savings strategies to ensure tax compliance. 


\section{References}

Abbas, A., Bashir, Z., Manzuor, S., and Akram, M.N. (2013). Determinants of firm's financial performance: An empirical study on textile sector of Pakistan. Business and Economic Research, Vol. 3 No 2 pp 77-86.

Ariwodola, J.A. (1991). Personal taxation in Nigeria $4^{\text {th }}$ Ed Lagos JAA limited.

Armstrong, C.S., Blouin, J.L., and Larcker, D.F. (2013). Corporate governance, incentives and tax avoidance, Rock Center for corporate governance working paper No.136. Stanford University, Stanford.

Bauer,P. (2004) Determinants of capital structure: empirical evidence from the Czech Republic. Czech. Journal of Economics and finance.

Chantana, A, Kawano, Y., Kamei, A., Minemoto, T. (2019). Description of degradation of output performance for photovoltaic modules by multiple regression analysis based on environmental factors. Optik - International Journal for Light and Electron Optics 179, 1063-1070

Cho, C., Kim, S., Kim, M-O (2017). Multiple quantile regression analysis of longitudinal data: Heteroscedasticity and efficient estimation Journal of Multivariate Analysis 155, 334-343

Dahunsi, S. O., Osueke, C. O., Olayanju, T. M. A. \& Lawal, A. I. (2019a). Effect of pretreatments on the chemical properties of Sorghum bicolor stalk for biogas Production. Energy Reports 5, 584-593

Dahunsi, S. O., Osueke, C.C., Olayanju, T. M. A. \& Lawal, A. I. (2019b). Co-digestion of Theobroma cacao (Cocoa) pod husk and poultry manure for energy generation: Effects of pretreatment methods. Bioresource Technology, 283, 229-245

Dare, F.D., and Sola (2010). Capital structure and corporate performance in Nigeria petroleum Industry: Panel data analysis. Journal of Mathematics and Statistics vol.6 No. 2 pp 168- 173.

Desai, M. (2003). The divergence between book and income tax. In: Poterba, J.M. (ed). Tax policy and the Economy. Cambridge: NBER and MIT press, 169-206.

Egger, P., Eggert, W. And Winner, H. (2010). Saving tax through foreign plant ownership. Journal of international economics, Vol. 81 pp 99-108.

Fakile, A. S. and Uwuigbe, O.R.(2013). Effect of strategic tax behaviour on corporate governance. International Journal of Finance and Accounting

Fashina, O. A., Asaleye, A.J., Ogunjobi, J.O., \& Lawal, A.I. (2018). Foreign aid, human capital and economic growth nexus: Evidence from Nigeria. Journal of International Studies, 11(2), 104-117. doi:10.14254/2071-8330.2018/11$2 / 8$

Frank, M.M., Lynch, L.J. and Rego, S.O. (2009). Tax reporting aggressiveness and its relation to aggressive financial reporting. The Accounting Review Vol. 84 No.2 pp 467-496.

Graham, J. (2003)." Taxes and corporate finance: A review" The review of Financial Studies Vol. 16 pp 1075 -1129.

Graham, J. and Tucker, A. (2006). Tax shelters and corporate debt policy. Journal of financial Economics. Vol. 81 Issue 3, p563.

Granger, C. W. J. and Newbold, P. (1974). Spurious regression in econometrics. University of Nottingham, Nottingham, England.

Hanlong, M. And Heitzman, S. (2010). A review of tax research. American journal of accounting and Economics. Vol. 50 No.2-3 pp 127-178.

Ho. J., Plewa, C., Lu, V. N. (2016). Examining strategic orientation complementarity using multiple regression analysis and fuzzy set QCA Journal of Business Research 69, 2199-2205

Im, K. S., Pesaran, M. and Shin, Y. (2003). Testing forunit roots in heterogeneous panels. Journal of Econometrics, 115(1), 53-74

Isola, A. I., Frank, A. and Leke, B. K. (2015). Can Nigeria achieve Millennium Development Goals? Journal of Social Science Research Volume 1, Issue 6, 1 October 2015, Pages 72-78

Jensen, H., Vandenbussche, K.C., (2005). Corporate tax savings when hiring a Big auditor: Empirical evidence for Belgium Catholic University of Leuven.

Kiabel, B.D. and Akenbor, C.O. (2014). Tax Planning and corporate Governance in Nigerian Banks. European Jpurnal of Business Management. Vol. 6 No. 19 pp 235-330.

Lawal, A. I., Asaleye, A.J., IseOlorunkanmi, J. \& Popoola, O. R. (2018c). Economic growth, agricultural output and tourism development in Nigeria: An application of the ARDL bound testing approach. Journal of Environmental Management and Tourism, 9(4), 786 - 794.

Lawal, A. I., Babajide, A. A., Nwanji, T. I., \& Eluyela, D. (2018a). Are Oil Prices Mean Reverting? Evidence from Unit Root Tests with Sharp and Smooth Breaks, International Journal of Energy Economics and Policy 8(6), 292-298 
Lawal, A. I., Fidelis, E. O., Babajide, A. A., Obasaju, O. B., Oyetade, O., Lawal-Adedoyin, B. \& Ojeka, J. D. (2018b). Impact of fiscal policy on agricultural output in Nigeria. Journal of Environmental Management and Tourism, 9(5), 1428-1442 https://doi.org/10.14505//jemt.v9.7(31).o8

Lawal, A. I., Nwanji, T. I., Asaleye, A. and Ahmed, V. (2016): Economic growth, financial development and trade openness in Nigeria: An application of the ARDL bound testing approach. Cogent Economics and Finance, 4:1258810, http://dx.doi.org/10.108o/23322039.2016.1258810

Lawal, A. I., Olayanju, A., Salisu, A. A., Asaleye, A. J., Dahunsi, O., Dada, O., Omoju, O. E., Popoola, O. R. (2019). Examining Rational Bubbles in oil prices: Evidence from frequency domain estimates. International Journal of Energy Economics and Policy 9(2), 166-173

Lawal, A. I., Somoye, R.O.C. and Babajide A. A. (2017): Are African stock markets efficient? Evidence from wavelet unit root test for random walk. Economic Bulletin, 37(4), pp. $1-16$

Levin, A., Lin, C-F., and Chu, Chu, C-S. J. (2002). Unit root tests in panel data: asymptotic and finite-sample properties. Journal of Econometrics, 108(1), 1-24

Majundar, S. And Chhibber, P. (1999). Capital Structure and performance: Evidence from a transition Economy on an aspect of corporate Governance. Netherlands, Kluwer Academic Publishers, Public Choice 98, 287-305.

Mills, L. (1999). Corporate tax compliance and financial reporting. National tax journal 49 (3) 421-435.

Mirza, S.A. and Javed, A. (2010). Determinants of financial performance of a firm: Case of Pakistan Stock Market. Journal of Economics and international Financial Vol. 5 No.4 pp 43-52.

Molina. C.A (2005). "Are firms under leveraged? An Examination of the effect of Leverage on default probabilities". Journal of Finance 6o, 1427-1459.

Nakaya, K., Tsuji, M., Chantana, J., Kawano, Y., Nishimura, T., Hishikawa, Y., \& Minemoto, T. (2020). Description of short circuit current of outdoor photovoltaic modules by multiple regression analysis under various solar irradiance levels. Renewable Energy 147. 895-902

Okere, W., Eluyela, F. D., Lawal, A.I., Oyebisi, I. Eseyin, O., Popoola, O., Awe, T.E. (2019). Foreign expatriates on board and financial performance: A study of listed deposit money banks in NigeriaThe Journal of Social Sciences Research 5 (2), 418-423https://doi.org/10.32861/jssr.52.418.423

Onaolapo, A.A. and Kajola, S. O. (2010). Capital structure and firm performance: Evidence from Nigeria. European Journal of Economics, Finance and Administrative Sciences, Issue 25.

Otekunrin, A. O. and Nwanji, T. I. and Olowookere, Johnson Kolawole and Egbide, Ben-Caleb and Fakile, Samuel Adeniran and Lawal, A. I. and Ajayi, Samuel Abiodun and Falaye, Adebanjo Joseph and Eluyela, F. D. (2018) Financial Ratio Analysis and Market Price of Share of Selected Quoted Agriculture and Agro-allied Firms in Nigeria After Adoption of International Financial Reporting Standard. The Journal of Social Sciences Research, 4 (12). pp. 736-744 https://arpgweb.com/journal/journal/7

Rajan, R. And Zingales, L. (1995). The Great Reversals. The politics of Financial Developments in the $20^{\text {th }}$ Century. National Bureau of Economics Research working paper, 8187.

Rego, S. (2003). Tax avoidance activities of USA Multinational Corporations. 20 Issue 4 805-833.

Rego, S. and Wilson,R. (2012). Equity risk incentives and corporate tax aggressiveness. Journal of Accounting Research 50, 775-810.

Salawu, R. O., Ogundipe, L. O. and Yeye, O. (2017). Granger causality between corporate tax planning and firm value of non-financial quoted companies in Nigeria. International Journal of Business and Social Science 8(9), 91-99

Shnoy, C. And Koch, D. (1996). The firm's leverage- cash flow relationship. Journal of Empirical Finance 2, $307-331$.

Shun, P. (1996). Taxes and corporate debt policy in Canada: An empirical investigation. Canadian Journal of Economics. 29, 556-572.

Titman, S. and Wessels, R. (1988). The determinants of capital structure choice. The Journal of Finance 43, 1-19.

Wang, X. (2010). Tax avoidance, Corporate Transparency and firm value. Working paper University of Texas.

Zeitun, R. (2009). Ownership Structure, Corporate performance and failure: Evidence from panel Data of Emerging Market the Case of Jordan Corporate ownership and control. 